\title{
Proteolytic Activation and Inactivation of Chitin Synthetase from Mucor rouxii
}

\author{
By JOSE RUIZ-HERRERA AND SALOMON BARTNICKI-GARCIA \\ Department of Plant Pathology, University of California, Riverside, \\ California 92502, U.S.A.
}

(Received 2 February 1976; revised 28 May 1976)

\author{
SUMMARY
}

Crude chitin synthetase preparations from the mycelial and yeast forms of Mucor rouxii behaved differently. The mycelial preparations, incubated at $28{ }^{\circ} \mathrm{C}$, lost virtually all chitin synthetase activity in a few hours; by contrast, the activity of enzyme preparations from yeast cells increased several fold during similar incubations. These spontaneous changes were probably caused by endogenous protease(s). Seemingly, the chitin synthetase in yeast preparations was present mainly in a latent, 'zymogenic', form that was activated by proteases. In the mycelial preparations, chitin synthetase was present mainly in an active state and was rapidly degraded by endogenous proteolysis. Exogenous proteases accelerated activation and destruction of chitin synthetase; an acid protease from Rhizopus chinensis was the most effective activator. The activation of chitin synthetase was inhibited by a soluble protein in the cell-free extract. Treatment with the detergent Brij 36T stabilized the chitin synthetase of crude preparations against spontaneous changes. Stabilized preparations were rapidly activated by exogenous proteases. The different behaviour of chitin synthetases in crude extracts of mycelium and yeast cells is consistent with, and perhaps partially responsible for, the differences in wall construction between mycelial and yeast forms of $M$. rouxii.

\section{INTRODUCTION}

Mucor rouxii is a dimorphic fungus capable of growing in either mycelial or yeast forms (Bartnicki-Garcia \& Nickerson, 1962). The properties of chitin synthetase from the mycelium of $M$. rouxii were determined by McMurrough, Flores-Carreon \& Bartnicki-Garcia (197I) and by McMurrough \& Bartnicki-Garcia (197I). Subsequently, we examined the chitin synthetase activity of crude fractions of the yeast form of $M$. rouxii (unpublished results). In most properties, the yeast enzyme was similar to the mycelial enzyme: both required a divalent metal, $\mathrm{Mn}^{2+}$ being slightly more effective than $\mathrm{Mg}^{2+}$; both were stimulated by $\mathrm{N}$-acetylglucosamine (GlcNAc); enzyme velocity was a sigmoidal function of substrate (UDP-GlcNAc) concentration; UDP and polyoxin were competitive inhibitors. There was one major difference between the yeast and mycelial chitin synthetases: enzyme stability. This communication compares the stability of yeast and mycelial chitin synthetase preparations, establishes the role of proteases in the activation and inactivation of chitin synthetase and discusses the significance of these findings in morphogenesis. A summary of this work has been published (Ruiz-Herrera \& Bartnicki-Garcia, 1975). 


\section{METHODS}

Cell fractionation. Mucor rouxii, strain IM-80 (ATCC24905), was grown on a solid YPG medium containing yeast extract, peptone, glucose and agar (Bartnicki-Garcia \& Nickerson, 1962). The spores were harvested in sterile distilled water, washed once with water by centrifugation, and used to inoculate 21 Erlenmyer flasks containing $600 \mathrm{ml}$ liquid YPG medium (final concentration: $1.5 \times 10^{5}$ to $3 \times 10^{5}$ spores $\mathrm{ml}^{-1}$ ). The flasks were placed in a reciprocating shaker bath at $28^{\circ} \mathrm{C}$ and incubated for $7 \mathrm{~h}$ (mycelium) or $\mathrm{I} 2 \mathrm{~h}$ (yeasts); the different morphological developments were achieved by using different atmospheres of incubation. Aerobic conditions were maintained by vigorously bubbling a stream of sterile air through the liquid medium. The resulting culture was a uniform suspension of incipent mycelial units. Anaerobic conditions were established with a stream of $\mathrm{N}_{2} / \mathrm{CO}_{2}(70: 30$, by vol.). The resulting culture was a suspension of yeast cells exclusively. Cells were harvested by filtration, washed with $0.05 \mathrm{M}$-buffer $\left(\mathrm{KH}_{2} \mathrm{PO}_{4} / \mathrm{NaOH}, \mathrm{pH} \mathrm{6}\right.$, , containing $\left.0.0 \mathrm{M} \mathrm{M}-\mathrm{MgCl}_{2}\right)$, resuspended in buffer, mixed with glass beads $(0.45$ to $0.50 \mathrm{~mm})$ and broken with a Braun MSK cell homogenizer. The cell-free extract was differentially centrifuged at $1000 \mathrm{~g}, 13000 \mathrm{~g}$, and $66000 \mathrm{~g}$ to obtain three pellets named, respectively, cell-wall fraction (CWF), low-speed membrane fraction (LMF), and high-speed membrane fraction (HMF), plus a soluble supernatant fraction (SSF). Alternatively, after separation of the CWF, the supernatant was centrifuged at $66000 \mathrm{~g}$ to sediment a mixed membrane fraction (MMF).

Enzyme assays. Chitin synthetase was measured in an incubation mixture containing, unless otherwise stated: $0.5 \mathrm{mM}-\mathrm{UDP}-\left[{ }^{14} \mathrm{C}\right] \mathrm{GlcNAc}\left(0.2 \mu \mathrm{Ci} \mu \mathrm{mol}^{-1}\right), 20 \mathrm{mM}-\mathrm{GlcNAc}, 0.2$ mM-ATP, Io mM- $\mathrm{MgCl}_{2}$ and $50 \mathrm{mM}-\mathrm{KH}_{2} \mathrm{PO}_{4} / \mathrm{NaOH}$ buffer, $\mathrm{pH} 6 \cdot 0$, in a final volume of $0.25 \mathrm{ml}$. The mixtures were incubated for $30 \mathrm{~min}$ at $22{ }^{\circ} \mathrm{C}$ and the reaction was stopped by adding $20 \mu \mathrm{l}$ glacial acetic acid. Radioactivity incorporated into chitin was measured by one of two methods. (I) Samples $(0.2 \mathrm{ml})$ were streaked on Whatman no. 3 paper strips $(4 \times 50 \mathrm{~cm})$ and the chromatograms were irrigated in descending fashion with $95 \%(\mathrm{v} / \mathrm{v})$ ethanol/ $\mathrm{I} \mathrm{M}$-acetic acid (70:30, by vol.) for about II $\mathrm{h}$. The radioactivity remaining at the origin was counted by liquid scintillation and assumed to be in chitin. (2) The whole incubation mixture was filtered through Whatman GF/C glass-fibre discs $(2.4 \mathrm{~cm})$ and washed with about $30 \mathrm{ml}$ $95 \%$ ethanol/1 $\mathrm{M}$-acetic acid (20:80, by vol.). The discs were dried in an oven at $70^{\circ} \mathrm{C}$, and placed in small $(3.5 \mathrm{ml})$ vials containing $3 \mathrm{ml}$ scintillation fluid. These were placed inside standard scintillation vials and counted. Both methods gave similar results. Activity was expressed as $\mathrm{nmol}\left[{ }^{14} \mathrm{C}\right] \mathrm{GlcNAc}$ incorporated into chitin per min. Specific activity was calculated per mg protein.

Endogenous protease activity was measured with either casein or acid-denatured haemoglobin (Schlamowitz \& Peterson, 1959). After I h at $22{ }^{\circ} \mathrm{C}$ the mixtures were precipitated with $0.3 \mathrm{M}$-trichloroacetic acid, and after $\mathrm{I} h$ at $0{ }^{\circ} \mathrm{C}$ were centrifuged at $1000 \mathrm{~g}$. The supernatant was assayed for peptide content with Folin's reagent (McDonald \& Chen, 1965). Specific activity of protease was expressed as nmol of non-precipitable (TCA) tyrosine produced per mg protein per hour.

Chitin synthetase inhibitor was measured by the procedure of López-Romero, RuizHerrera \& Bartnicki-Garcia (unpublished). MMF from yeast cells of $M$. rouxii was resuspended in $0.05 \mathrm{M}$-phosphate buffer, $\mathrm{pH} 6.0$, with $10 \mathrm{mM}-\mathrm{MgCl}_{2}$ and treated with ro $\mathrm{mm}^{-}$ Brij 36T for $\mathrm{I} \mathrm{h}$ at $0{ }^{\circ} \mathrm{C}$. It was then sedimented at $66000 \mathrm{~g}$ for $45 \mathrm{~min}$ and washed twice with buffer by centrifugation at the same speed. The Brij-treated MMF was incubated with $20 \mathrm{mM}$-GlćNAc, $0.2 \mathrm{mM}$-ATP and $0.5 \mathrm{mM}$-UDP-[ $\left.{ }^{14} \mathrm{C}\right] \mathrm{GlcNAc}\left(0.2 \mathrm{mCi} \mathrm{mmol}^{-1}\right)$ in the presence of trypsin $\left(400 \mu \mathrm{g} \mathrm{ml}^{-1}\right)$ and several dilutions of inhibitor-containing SSF for $30 \mathrm{~min}$ 


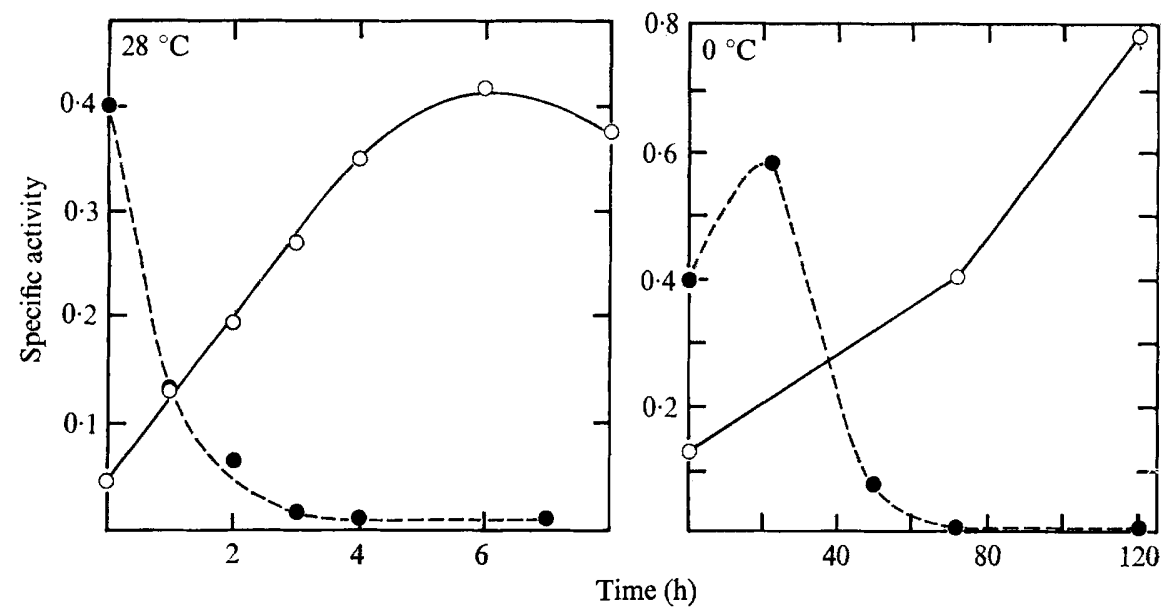

Fig. I. Activation and inactivation of chitin synthetase from yeast $(O)$ and mycelial $(0)$ forms of Mucor rouxii at 28 or $0^{\circ} \mathrm{C}$. The HMF was resuspended in phosphate/ $\mathrm{Mg}^{2+}$ buffer and incubated at either 28 or $0^{\circ} \mathrm{C}$. Samples $(0 . \mathrm{I} \mathrm{ml} ; 2.36 \mathrm{mg}$ protein for the yeast enzyme and $\mathrm{I} \cdot 24 \mathrm{mg}$ for the mycelial enzyme) were withdrawn at intervals and chitin synthetase activity was measured at $22{ }^{\circ} \mathrm{C}$ by incubation with UDP-[ $\left.{ }^{14} \mathrm{C}\right] \mathrm{GlcNAc}$ and activators for $30 \mathrm{~min}$. Chitin synthesized was measured by the paper chromatography method. Specific activities are expressed as nmol GlcNAc incorporated (mg protein) ${ }^{-1} \mathrm{~min}^{-1}$.

at $22{ }^{\circ} \mathrm{C}$. Chitin synthesized was measured as described above, and the percentage inhibition caused by I mg SSF protein was calculated.

Miscellaneous. Radioactivity on paper chromatograms and glass-fibre discs was counted in scintillation fluid [0.I $\mathrm{g} \mathrm{I}, 4$-bis[2-(4-methyl-5-phenyloxazolyl)]benzene and $2.0 \mathrm{~g}$ 2,5-diphenyloxazole dissolved in I 1 toluene]. Aqueous samples were counted with Aquasol (New England Nuclear). Protein was measured with Folin's phenol reagent (Lowry et al., 195I).

Hamersten casein and crystalline trypsin were from Nutritional Biochemicals (Cleveland, Ohio, U.S.A.); crystalline $\alpha$-chymotrypsin and pronase from Calbiochem; and acid protease from Rhizopus chinensis from Miles Laboratories (Elkhart, Indiana, U.S.A.). Mexicain, a crystalline protease from Pileus mexicanus (Castañeda-Agulló et al., 1945), was a gift from Professor M. Castañeda-Agulló, Instituto Politécnico Nacional, México. The detergent Brij 36T, a product from Atlas de México, México D. F., was obtained through the courtesy of C. Gitler, CIEA, Instituto Politécnico Nacional, México. Crude bovine haemoglobin, UDPGlcNAc and phenylmethylsulphonyl fluoride were purchased from Sigma; and UDP- $\left[{ }^{4} \mathrm{C}\right]$ GlcNAc was from ICN (Irvine, California, U.S.A.).

Enzyme samples (Io ml) were sonicated in a Biosonik III unit (Bronwill Scientific Co., San Mateo, California, U.S.A.) adjusted to maximum acoustic efficiency (setting of 75).

\section{RESULTS}

Stabilities of mycelial and yeast chitin synthetases. The stabilities of crude chitin synthetase preparations from mycelium and yeast cells of $M$. rouxii differed dramatically. On incubation at $28^{\circ} \mathrm{C}$, the chitin synthetase activity of mycelial HMF was virtually lost within $2 \mathrm{~h}$ (Fig. I). In sharp contrast, the chitin synthetase activity of yeast HMF rose and reached a maximum (nearly a ro-fold increase) after $6 \mathrm{~h}$ incubation at $28^{\circ} \mathrm{C}$. With continued incubation the net chitin synthetase activity began to decline. These changes were temperature dependent. At $0{ }^{\circ} \mathrm{C}$, the same behaviour occurred but at a much slower rate. The mycelial 
Table I. Activation of chitin synthetase in subcellular fractions from yeast cells of Mucor rouxii stored at $0{ }^{\circ} \mathrm{C}$

Cell-free extracts were fractionated (see Methods) and assayed for chitin synthetase activity. (Cellwall fraction was washed to times with buffer before assay.) Fractions were then kept over ice in a cold room, and their activities were measured again after 48 and $96 \mathrm{~h}$. Total activities are expressed as nmol GIcNAc incorporated into chitin $\min ^{-1}$ by each entire fraction.

\begin{tabular}{ccrr} 
Time & \multicolumn{3}{c}{ Chitin synthetase activity } \\
\cline { 2 - 3 } (h) & CWF & \multicolumn{1}{c}{ LMF } & HMF \\
0 & 1.36 & 7.59 & 3.75 \\
48 & 4.46 & 8.53 & 16.66 \\
96 & 7.87 & 13.56 & 55.80
\end{tabular}

enzyme activity disappeared in 2 to 3 days (Fig. I) whereas the yeast enzyme activity increased (Fig. I) for 7 days and then began to decline (not shown). At this low temperature, an initial rise was detected in the mycelial enzyme activity before the decline.

Of the three subcellular fractions from yeast cells, the LMF initially had the highest chitin synthetase activity (Table I). However, this increased only $\mathrm{I} \cdot 8$-fold on storage at $0{ }^{\circ} \mathrm{C}$ for $96 \mathrm{~h}$. In contrast, the activity of the HMF increased 14 -fold and ultimately became the most active fraction. The CWF was activated to an intermediate level $(5 \cdot 8$-fold).

Endogenous proteolytic activity of $M$. rouxii. The MMF from mycelium of $M$. rouxii had proteolytic activity in the $\mathrm{pH}$ range 2 to 8 (Fig. 2). The protease activities of mycelial and yeast MMF were compared at $\mathrm{pH} 3.0$ (haemoglobin) and $\mathrm{pH} 6.0$ (casein). The protease specific activity in the mycelial MMF was always higher, although the differences ranged from 2- to 7-fold in separate experiments.

Effect of a protease inhibitor. Phenylmethylsulphonyl fluoride, at $0 \cdot 1$ to $\mathrm{I} \cdot 3 \mathrm{mM}$, had no noticeable effect on the stability of chitin synthetase (MMF) prepared from either the mycelium or yeast cells of $M$. rouxii and stored at either 28 or $0^{\circ} \mathrm{C}$.

Activation of chitin synthetase by exogenous proteases. Several proteases were added, at various concentrations, to standard chitin synthetase assays. All of them increased chitin synthetase activity but to different extents (Fig. 3), the most effective being the acid protease from Rhizopus chinensis. Trypsin and pronase were highly stimulatory at $80 \mu \mathrm{g} \mathrm{ml}^{-1}$, but at higher concentrations the net chitin synthetase activity was low probably because of proteolytic degradation. In making these comparisons of protease efficacy, one should keep in mind that the tests were done at a $\mathrm{pH}(6 \cdot 0)$ favourable for chitin synthetase and not at the $\mathrm{pH}$ optimum for each protease.

The addition of $R$. chinensis protease to MMF from yeast cells of $M$. rouxii increased both the rate of activation and the maximum level of chitin synthetase (compare Figs $4 a$ and I). Acid protease also affected mycelial chitin synthetase although the net effect was less pronounced; activity increased briefly and then decayed rapidly (Fig. $4 b$ ).

Soluble inhibitor of chitin synthetase activation. The SSF of $M$. rouxii contains a soluble inhibitor of chitin synthetase activation (McMurrough \& Bartnicki-Garcia, 1973). Addition of crude SSF from yeast cells $\left(14 \mathrm{mg} \mathrm{ml}^{-1}\right)$ to the HMF from the same cells $\left(8.4 \mathrm{mg} \mathrm{ml}^{-1}\right)$ in a standard chitin synthetase assay, slowed down the rate of activation by almost $50 \%$. We found that SSF of yeast cells contained 2.5 times more inhibitor per mg protein than the mycelial SSF.

Stabilization of chitin synthetase with Brij $36 T$. The crude chitin synthetase from $M$. rouxii survived the action of anionic (sodium dodecyl sulphate) and neutral (Brij 36T) detergents. 


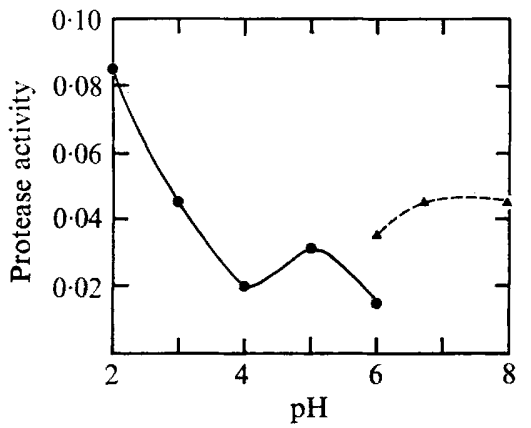

Fig. 2

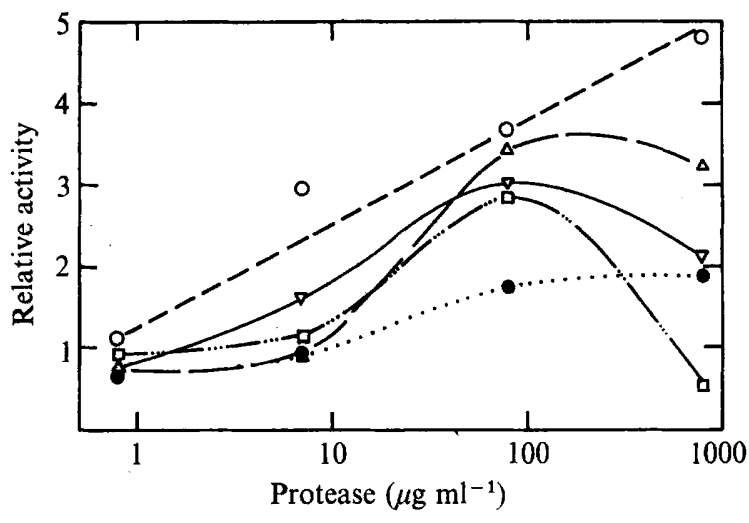

Fig. 3

Fig. 2. Proteolytic activity of mycelial MMF. Samples of MMF in phosphate/ $\mathbf{M g}^{2+}$ buffer were adjusted to the indicated $\mathrm{pH}$ values with $\mathrm{HCl}$ or $\mathrm{NaOH}$ and incubated with acid-denatured haemoglobin $(\boldsymbol{O})$ or casein $(\boldsymbol{\Delta})$ to measure protease activity, expressed as nmol soluble tyrosine (mg protein) $)^{-1} \mathbf{h}^{-1}$.

Fig. 3. Effect of proteases on chitin synthetase activity of yeast MMF. The indicated amounts of protease solutions (freshly prepared in phosphate $/ \mathrm{Mg}^{2+}$ buffer, $\mathrm{pH} \mathrm{6.0)} \mathrm{were} \mathrm{added} \mathrm{to} \mathrm{standard}$ chitin synthetase assays. Reaction was started by adding MMF ( $0.2 \mathrm{ml} ; 1.68 \mathrm{mg}$ protein). After $30 \mathrm{~min}$, the reaction was stopped by adding acetic acid and the synthesized chitin was measured by the paper chromatography method. Specific activities were calculated and are expressed relative to that of a control without protease $(\mathrm{I} \cdot 00)$. The control had a specific activity of $0.14 \mathrm{nmol}$ GlcNAc incorporated (mg protein) ${ }^{-1} \min ^{-1}$. $O$, Acid protease; $\Delta$, mexicain; $\nabla$, trypsin; $\square$, pronase; , chymotrypsin.
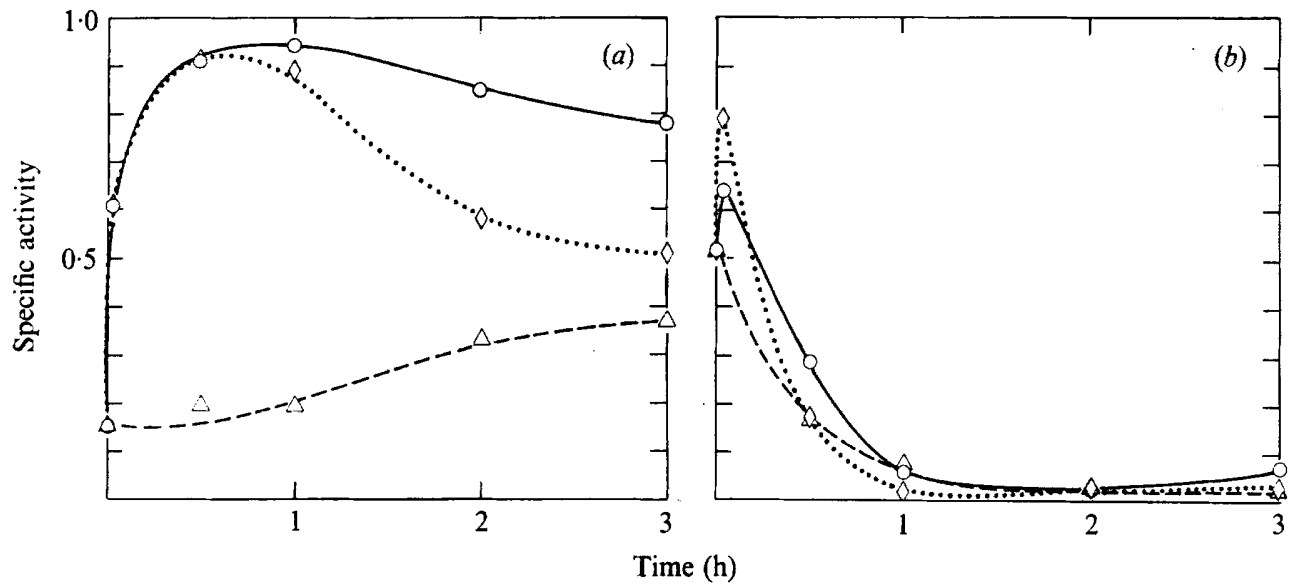

Fig. 4. Effect of acid protease on (a) yeast and (b) mycelial chitin synthetases. MMF was obtained from yeast and mycelial cells and resuspended in phosphate/ $\mathbf{M g}^{2+}$ buffer. Samples were incubated at $28{ }^{\circ} \mathrm{C}$ with or without addition of acid protease. At intervals, samples $(0.2 \mathrm{ml} ; 3.3 \mathrm{mg}$ protein for the mycelial enzyme and $1 \cdot 7 \mathrm{mg}$ for the yeast enzyme) were withdrawn and chitin synthetase activity was measured for $30 \mathrm{~min}$ at $22^{\circ} \mathrm{C}$. Chitin synthesized was measured by the filtration method. Specific activities are expressed as nmol GlcNAc incorporated $\min ^{-1}(\mathrm{mg} \text { protein })^{-1} . \Delta$, No addition; $\diamond$, acid protease at $26.6 \mu \mathrm{g} \mathrm{ml}^{-1}$; $\bigcirc$, acid protease at $133 \mu \mathrm{g} \mathrm{ml}^{-1}$. 


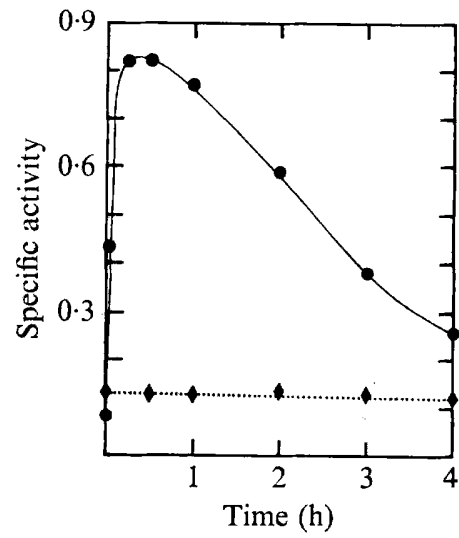

Fig. 5. Effect of acid protease on the activation of Brij-treated yeast chitin synthetase. MMF was isolated and treated with $5 \mathrm{~mm}-\mathrm{Brij} 36 \mathrm{~T}$ at $0^{\circ} \mathrm{C}$ for $\mathrm{I} \mathrm{h}$. It was then centrifuged at $66000 \mathrm{~g}$ for $45 \mathrm{~min}$, washed twice with buffer and resuspended in buffer. Samples $\left(2 \cdot 82 \mathrm{mg}\right.$ protein $\left.\mathrm{ml}^{-1}\right)$ were incubated at $28^{\circ} \mathrm{C}$ with $(\Theta)$ or without $(\diamond)$ acid protease at $50 \mu \mathrm{g} \mathrm{ml}^{-1}$. At intervals, $0.2 \mathrm{ml}$ samples were removed for chitin synthetase assay. Activities are expressed as nmol GlcNAc incorporated (mg protein) $)^{-1} \min ^{-1}$.

Although the surfactants interfered with enzyme operation, most of the chitin synthetase activity in the MMF was recovered in the pellet after removing the surfactant by centrifuging Furthermore, Brij-treated samples of yeast chitin synthetase did not undergo spontaneous changes. Thus when a yeast MMF pellet was treated with ro mM-Brij for $30 \mathrm{~min}$ at $0^{\circ} \mathrm{C}$, centrifuged at $66000 \mathrm{~g}$ to remove the detergent, and washed twice with phosphate $/ \mathrm{Mg}^{2+}$ buffer by centrifugation, its chitin synthetase activity became quite stable and no appreciable change was observed after $4 \mathrm{~h}$ at $28^{\circ} \mathrm{C}$ (Fig. 5) or $96 \mathrm{~h}$ at $0^{\circ} \mathrm{C}$ (compare with the results for untreated enzyme, Fig. I).

The supernatant obtained after treatment of MMF with Brij 36T was adjusted to $70 \%$ saturation with $\left(\mathrm{NH}_{4}\right)_{2} \mathrm{SO}_{4}$. The resulting precipitate was separated by centrifuging at $3000 \mathrm{~g}$ for ro min and dialysed against $0.05 \mathrm{M}$-phosphate buffer with Io mM- $\mathrm{MgCl}_{2}$, $\mathrm{pH} 6.0$. Measurement of protease activity at $\mathrm{pH} 3.0$ (haemoglobin) and $\mathrm{pH} 6.0$ (casein) indicated that most of the protease ( $85 \%$ ) was in the supernatant and the remainder in the detergentextracted MMF.

Activation of Brij-stabilized chitin synthetase. When yeast MMF, previously stabilized with Brij, was treated with acid protease $\left(50 \mu \mathrm{g} \mathrm{ml}^{-1}\right)$, its chitin synthetase activity increased sharply and then rapidly decayed (Fig. 5). Other proteases (trypsin, papain, mexicain) were also effective but the activation was considerably smaller.

Effect of sonic oscillation on chitin synthetase activity. Cabib \& Farkas (197I) found that a mild sonic oscillation depressed the chitin synthetase activity of particulate fractions of Saccharomyces spp. and released the activating protease. In $M$. rouxii, we found the opposite; sonication for as long as $6 \mathrm{~min}$ increased the chitin synthetase activity of the MMF sample. After centrifuging, the sonicated MMF pellet showed seven times more activity than the original sample. The net chitin synthetase activity of the sonicated pellet did not increase further on subsequent incubation at $28^{\circ} \mathrm{C}$; there was only a gradual decrease $(40 \%$ in $3 \mathrm{~h})$.

When the supernatant of the sonicated MMF sample was recombined with the sonicated MMF pellet, its chitin synthetase activity decreased by about $50 \%$ and remained essentially unchanged for the next $3 \mathrm{~h}$. Clearly, sonication released a soluble inhibitor of the activation 
process and this may be the main reason for the rapid rate of activation of chitin synthetase during sonication.

\section{DISCUSSION}

Stability of crude chitin synthetases. The levels of chitin synthetase activity in crude cellfree extracts from different fungi are highly variable (Jaworski, Wang \& Carpenter, 1965; Porter \& Jaworski, 1966; Camargo et al., 1967; McMurrough et al., 1971; McMurrough \& Bartnicki-Garcia, 1971; Myers \& Cantino, 1974). Depending on storage conditions and source organism, spontaneous increases and/or decreases in chitin synthetase activity have been observed in crude preparations. Some of these changes are caused by endogenous proteases. Thus, in Saccharomyces spp., Cabib \& Farkas (1971) and Cabib \& Ulane (1973) found that chitin synthetase existed in a 'zymogenic' form and was activated by exogenous or endogenous proteases. Prolonged incubation with protease destroyed chitin synthetase (Hasilik, 1974). We observed a similar activation and destruction of chitin synthetase in preparations from yeast cells of Mucor rouxii.

Regulation of chitin synthetase by proteolysis. The wide fluctuation of chitin synthetase activity in the cell-free extracts of $M$. rouxii can be explained as a result of two processes: activation of a latent (zymogen ?) form of the enzyme, and irreversible destruction. Both are probably caused by endogenous protease(s). This is supported by several findings: (i) exogenous proteases accelerate activation of chitin synthetase; (ii) chitin synthetase preparations have proteolytic activity; and (iii) the chitin synthetase activity in preparations from $M$. rouxii yeast cells was stabilized by treatment with the neutral detergent Brij $36 \mathrm{~T}$. The detergent eliminated most of the endogenous protease, and the chitin synthetase activity of the preparations remained fairly constant for several days at $0{ }^{\circ} \mathrm{C}$. On addition of protease, the Brij-stabilized enzyme was quickly activated to high levels. Sodium cholate had a similar action on chitin synthetase of Saccharomyces cerevisiae (Cabib et al., 1973). Likewise, Gooday \& de Rousset-Hall (1975) noted that digitonin increased the stability of chitin synthetase from Coprinus cinereus. This treatment also solubilized the enzyme.

The chitin synthetase system of $M$. rouxii, like that of Saccharomyces (Cabib \& Farkas, 197 ; Cabib et al., 1973), consists of at least three major components: a glycosyl transferase; an activating protease; and a soluble protein inhibitor. According to Cabib and co-workers, the glycosyl transferase is present in the cell plasmalemma in a zymogenic state and is later activated by a protease present in a different cell compartment. The soluble inhibitor blocks the action of the protease and serves as a safety mechanism to avoid spurious activation. Our findings suggest a somewhat similar mechanism of activation of chitin synthetase. Presumably, the protease and the glycosyl transferase are in different subcellular compartments and begin to interact after being discharged to the cell surface.

Although the term 'zymogen' has been used to describe the inactive or latent form of chitin synthetase (Cabib \& Farkas, 1971), the actual cause of this latency has not been established.

The presence of a soluble inhibitor of chitin synthetase in $M$. rouxii (McMurrough \& Bartnicki-Garcia. 1973) was confirmed. The cell-free extracts from yeast cells of $M$. rouxii contained 2.5 times more inhibitor than those from mycelium. The properties of the inhibitor will be described elsewhere.

Mycelial versus yeast chitin synthetases. The behaviour of chitin synthetases in cell-free extracts from mycelium and yeast forms of $M$. rouxii was markedly different. In the mycelium cell-free extracts, most of the chitin synthetase was already in an active state (or reached it during the assay), and only a small initial activation could be noted; otherwise, continued 
incubation at room temperature caused a rapid destruction. In sharp contrast, the yeast chitin synthetase was mostly present in a latent state that was slowly activated and eventually destroyed by endogenous proteases. Addition of exogenous proteases accelerated these processes.

Barring primary differences in the molecular structure of chitin synthetases from the mycelium or yeast cells of $M$. rouxii, the pronounced discrepancy in stability and activation of the crude enzymes may result from the interplay between protease and inhibitor. Thus a high level of protease and low level of inhibitor in the mycelium would result in a short-lived chitin synthetase. Conversely, in yeast cells, a low protease level and a high inhibitor concentration would combine to make chitin synthetase long-lived.

Morphogenetic implications. The pattern of wall construction is probably a determinant of cellular shape in most fungi (Bartnicki-Garcia, 1973). This is clearly apparent in the dimorphic fungus $M$. rouxii (Bartnicki-Garcia \& Lippman, 1969). The hyphal (mycelial) form results from a polarized pattern of wall growth. A sharp gradient of wall synthesis exists at the tip of the apically growing tubular cell. The hyphal tube elongates without substantial change in wall thickness. By contrast, the spherical yeast cells expand isodiametrically by uniform deposition of wall components throughout the cell surface. There is also a gradual but substantial increase in wall thickness in the yeast cell (Lara \& Bartnicki-Garcia, 1974). These two patterns of wall construction must be dictated by spatial and temporal controls on wall microfibril synthesis. The role of cytoplasmic vesicles in determining the spatial distribution of wall synthesizing enzymes, such as chitin synthetase, has been considered (Girbardt, 1969; Grove, Bracker \& Morré, 1970; Bartnicki-Garcia, 1973); as to temporal controls, our present findings indicate that the onset of activity and life-span of chitin synthetase may be regulated by proteolysis. The short life of the mycelial chitin synthetase is consistent with the observed sharp gradient of chitin synthesis in the hyphal apex (BartnickiGarcia \& Lippman, 1969; McMurrough et al., 1971). Enzyme initially deposited on the wall of the apical dome would be rapidly inactivated during the transition from tip wall to lateral wall. In yeast cells, inactivation of chitin synthetase may not be critical and the longer life of the enzyme would account for the thicker walls of the mature yeast cell (Lara \& BartnickiGarcia, 1974).

This work was supported in part by research grant AI 05440 from the National Institutes of Health, United States Public Health Service and grants 020 and 847 from CONACYT, Mexico.

J.R-H., on leave from Escuela Nacional de Ciencias Biológicas, Instituto Politécnico Nacional, México I7, D. F. México, was professorial fellow from the COFAA of the Instituto Politécnico Nacional.

\section{REFERENCES}

BARTNICKI-Garcia, S. (1973). Fundamental aspects of hyphal morphogenesis. Symposia of the Society for General Microbiology 23, 245-267.

BARTNICKI-GARCIA, S. \& LIPPMAN, E. (1969). Fungal morphogenesis: cell wall construction in Mucor rouxii. Science 165, 302-304.

BARTNICKI-GARCIA, S. \& NICKERSON, W. J. (1962). Induction of yeast-like development in Mucor by carbon dioxide. Journal of Bacteriology 84, 829-840.

CABIB, E. \& FARKAS, V. (1971). The control of septum morphogenesis: an enzymatic mechanism for the initiation of septum formation. Proceedings of the National Academy of Sciences of the United States of America 68, 2052-2056.

CABIB, E. \& UlANE, R. (1973). Chitin synthetase activating factor from yeast, a protease. Biochemical and Biophysical Research Communications 50, 186-191. 
Cabib, E., Farkas, V., Ulane, R. E. \& Bowers, B. (1973). Yeast septum formation as a model system for morphogenesis. In Yeast, Mould and Plant Protoplasts, pp. 105-II6. Edited by J. R. Villanueva, I. Garcia-Acha, S. Gascon and F. Uruburu. London: Academic Press.

Camargo, E. P., Dietrich, C. P., Sonneborn, E. \& Strommger, J. L. (1967). Biosynthesis of chitin in spores and growing cells of Blastocladiella emersonii. Journal of Biological Chemistry 242, 31 2 I-3 28.

Castañeda-Agulló, M., Hernandez, A., Loaeza, F. \& Salazar, W. (I945). Crystallization of mexicain. Journal of Biological Chemistry 159, $75 \mathrm{I}$.

Girbardt, M. (1969). Die Ultrastruktur der Apikalregion von Pilzhyphen. Protoplasma 67, 413-441.

GoOdAy, G. W. \& DE Rousset-HaLl, A. (1975). Properties of chitin synthetase from Coprinus cinereus. Journal of General Microbiology 89, 137-145.

Grove, S. N., Bracker, C. E. \& Morré, D. J. (1970). An ultrastructural basis for hyphal tip growth in Pythium ultimum. American Journal of Botany 57, 245-266.

HASILIK, A. (1974). Inactivation of chitin synthase in Saccharomyces cerevisiae. Archives of Microbiology IOI, 295-30I.

JAWORSKI, E. G., WANG, L. C. \& CARPENTER, W. D. (1965). Biosynthesis of chitin in cell-free extracts of Venturia inaequalis. Phytopathology 55, 1309-1312.

LARA, S. L. \& BARTNICKI-GARCIA, S. (1974). Cytology of budding in Mucor rouxii: wall ontogeny. Archives of Microbiology 97, 1-16.

Lowry, O. H., Rosebrough, N. J., FarR, A. L. \& Randall, R. J. (195I). Protein measurements with the Folin phenol reagent. Journal of Biological Chemistry I93, 265-275.

McDonald, C. E. \& CHEN, L. L. (1965). The Lowry modification of the Folin reagent for determination of proteinase activity. Analytical Biochemistry 10, 175-177.

McMurrough, I. \& BartniCKI-Garcia, S. (I97I). Properties of a particulate chitin synthetase from Mucor rouxii. Journal of Biological Chemistry 246, 4008-40I6.

McMurrough, I. \& Bartnicki-Garcia, S. (I973). Inhibition and activation of chitin synthesis by $M u c o r$ rouxii cell extracts. Archives of Biochemistry and Biophysics 158, 8 12-816.

McMurrough, I., Flores-Carreon, A. \& Bartnicki-Garcia, S. (I97I). Pathway of chitin synthesis and cellular localization of chitin synthetase in Mucor rouxii. Journal of Biological Chemistry 246, 3999-4007.

Myers, R. B. \& Cantino, E. C. (1974). The Gamma Particle, Monographs in Developmental Biology, vol. 8. Basel: S. Karger.

PoRTER, C. A. \& JAwORski, E. G. (I966). The synthesis of chitin by particulate preparations of Allomyces macrogynus. Biochemistry, New York 5, I I49-1 I 54.

RUIZ-HERRERA, J. \& BARTNICKI-GARCIA, S. (1975). Biochemistry of dimorphism: proteolytic activation and destruction of chitin synthetase from Mucor rouxii. Abstracts of the Annual Meeting of the American Society for Microbiology, p. 130. Washington: American Society for Microbiology.

Schlamowitz, M. \& Peterson, L. U. (1959). Studies on the optimum pH for the action of pepsin on 'native' and denatured bovine serum albumin and bovine hemoglobin. Journal of Biological Chemistry 234, 3137-3145. 